\title{
Geochemical Proxies and Mineralogical Fingerprints of Sedimentary Processes in a Closed Shallow Lake Basin Since 1850
}

\author{
Paola Gravina ${ }^{1}$ - Alessandro Ludovisi ${ }^{1} \cdot$ Beatrice Moroni ${ }^{1} \cdot$ Riccardo Vivani $^{2}$. \\ Roberta Selvaggi ${ }^{1}$. Chiara Petroselli ${ }^{3}$. David Cappelletti ${ }^{1}$
}

Received: 2 September 2021 / Accepted: 21 January 2022 / Published online: 13 February 2022

(C) The Author(s) 2022

\begin{abstract}
Lake systems are essential for the environment, the biosphere, and humans but are highly impacted by anthropogenic activities accentuated by climate change. Understanding how lake ecosystems change due to human impacts and natural forces is crucial to managing their current state and possible future restoration. The high sensitivity of shallow closed lakes to natural and anthropogenic forcing makes these lacustrine ecosystems highly prone to variations in precipitation and sedimentation processes. These variation processes, occurring in the water column, produce geochemical markers or proxies recorded in lake sedimentary archives. This study investigated specific proxies on high-resolution sedimentary archives (2-3 years resolution) of the Trasimeno lake (Central Italy). The Trasimeno lake underwent three different hydrological phases during the twentieth century due to several fluctuations induced mainly by human activities and climate change. The Trasimeno lake, a large and shallow basin located in the Mediterranean area, is a good case study to assess the effects of intense anthropogenic activity related to agriculture, tourism, industry, and climate changes during the Anthropocene. The aim is to identify the main characteristics of the main sedimentary events in the lake during the last 150 years, determining the concentrations of major and trace elements, the amount of organic matter, and the mineralogical composition of the sediments. This type of work demonstrates that studying sediment archives at high resolution is a viable method for reconstructing the lake's history through the evolution/trends of the geochemical proxies stored in the sediment records. This effort makes it possible to assess past anthropogenic impact and, under the objectives of the European Green Deal (zero-pollution ambition for a toxic-free environment), to monitor, prevent, and remedy pollution related to soil and water compartments.
\end{abstract}

Paola Gravina

paolagravi@gmail.com

1 Department of Chemistry, Biology and Biotechnology, University of Perugia, 06123 Perugia, Italy

2 Department of Pharmaceutical Sciences, University of Perugia, Perugia, Italy

3 Faculty of Engineering and Physical Sciences, University of Southampton, 12 University Road, Southampton SO17 1BJ, UK 


\section{Graphical abstract}

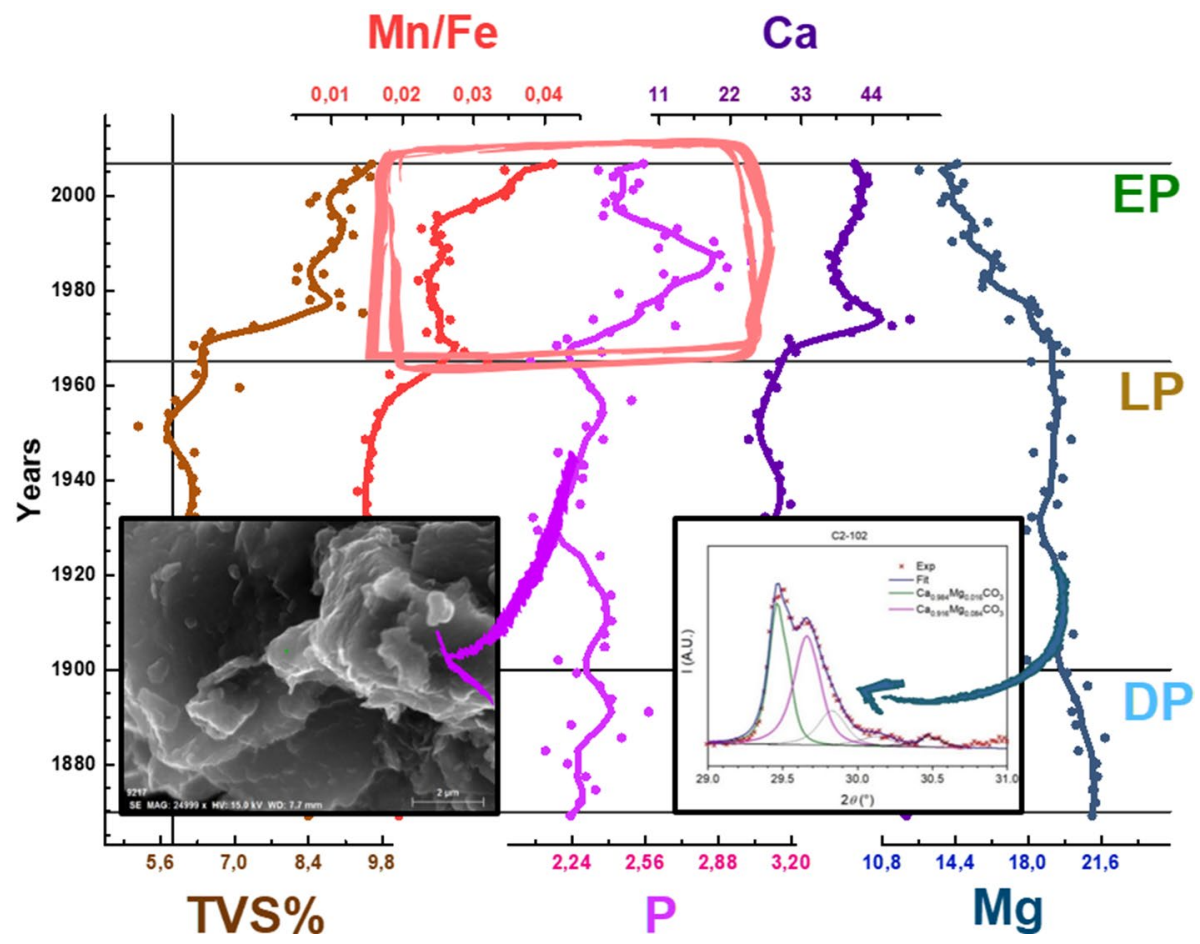

Keywords Shallow lake $\cdot$ Hydrological variation $\cdot$ Sediment cores $\cdot$ Carbonates

$\mathrm{Mg}$-calcite $\cdot \mathrm{P}$ precipitation

\section{Introduction}

Lake systems are fundamentally important for the environment, the biosphere, and humans, as they contain one of the accessible freshwater portions, are habitats for wide variety of plants and animals, and have always been the basin for civilisation (Smol et al. 2001). However, the lakes are highly impacted by anthropogenic activities, accentuated by climate change (Dubois et al. 2018). Understanding how lake ecosystems change, due to human impacts (such as agricultural activities, domestic sewage, atmospheric deposition, and industrial effluents) and natural forces (such as weather conditions and geological weathering), is crucial to manage their current state and future restoration (Morellón et al. 2011).

During the last few centuries, anthropic water use and pollution has amplified the meteo-climatic effects on lake basins (Ludovisi and Gaino 2010), and these effects have been particularly severe in Mediterranean and Sub-Mediterranean areas (Corella et al. 2013; Damnati et al. 2016), where water resources are scarce (Valero-Garcés et al. 2006).

Shallow lake is well suited for investigating anthropogenic and natural changes in the past (Guerra et al. 2015), because they are more susceptible than other lakes to bioturbation, sediment mixing processes, weather variations, and climate change. Indeed, 
when shallow lakes are impacted by internal and external forcing, it responds rapidly (Martín-Puertas et al. 2011) through marked changes in the physical-chemical and biological properties of the water column and consequently in the mineralogical composition of the sediment.

The study of high-resolution lake sedimentary records provides an opportunity to unravel the anthropogenic and natural processes that have occurred on lake ecosystem (Guerra et al. 2015), as the geochemical and mineralogical stratigraphy contains important historical information (Gierlowski-Kordesch 2010; Dubois et al. 2018), regarding several processes as changes in primary productivity by autotrophic species, nutrient level variations, eutrophication, and other natural and anthropogenic phenomena (Zan et al. 2011; Yamamuro and Kanai 2005). In the present paper, we will focus on the sedimentary and precipitation processes driven by the substantial water level fluctuations of the Trasimeno lake (Central Italy). Specific geochemical markers will be investigated in the sedimentary records, as $\mathrm{Mn} / \mathrm{Fe}$ ratio which is used to reconstruct changes in redox conditions in lakes, and can be connected to the behaviour of certain microorganisms and their primary production activities.

Other proxies, e.g. specific elemental ratios ( $\mathrm{Ca} / \mathrm{Al}, \mathrm{Mg} / \mathrm{Ca}, \mathrm{K} / \mathrm{Al}$ and $\mathrm{Mg} / \mathrm{Al}$ ), can be used in combination with knowledge of the mineralogical composition of the sediment, indicating how the distribution of certain elements evolves within different mineralogical phases in the sediment. The mineralogy of lake sedimentary archives depends on the precipitation/sedimentation processes within the water column and is influenced by biotic and abiotic factors (Gierlowski-Kordesch 2010). The sedimentary archives of many lakes incorporate autochtonous precipitates generated by processes that greatly influence the ecosystem of the lake (Koschel et al. 1990; Murphy et al. 1983). Among the most common and abundant autochthonous precipitates, there are calcite $\left(\mathrm{CaCO}_{3}\right)$ and dolomite $\left(\mathrm{CaMg}\left(\mathrm{CO}_{3}\right)_{2}\right)$ (Sánchez-Román et al. 2011).

The precipitation of calcite can influence the dynamics of aquatic microorganisms (e.g. phytoplankton) and algal productivity in various ways, for example, by lowering the availability of inorganic and organic compounds in water, following co-precipitation between calcite and other elements (e.g. phosphorus and magnesium) (Otsuki and Wetzel 1972) or by increasing the sedimentation rate (Koschel et al. 1990). Although it is well known that autochthonous calcite precipitation is more common in hard water lakes, it has not been clarified whether phosphorus concentration can influence the magnitude and dynamics of calcite precipitation (Dittrich and Koschel 2002). Given its ecological significance in the control of eutrophication phenomena, co-precipitation of inorganic phosphate with calcite has been extensively studied. (Hartley et al. 1997). In this study, we will use some specific geochemical proxies, such as the $\mathrm{Mn} / \mathrm{Fe}$ ratio, $\mathrm{Ca}$, and $\mathrm{P}$, together with the measurement of organic matter, to investigate the co-precipitation process of calcium-phosphate mineralogical phases.

The mineralogy of the precipitates contained in sediment records also depends on the concentration of dissolved ions (e.g. $\mathrm{HCO}_{3}^{-}, \mathrm{Mg}^{+2}$ and $\mathrm{Ca}^{+2}$ ) in the water, which can lead to the formation of calcite, dolomite, aragonite, and hydromagnesite (RodriguezBlanco et al. 2014; Zhang et al. 2012) of different origins such as endogenic and/or biogenic (Stabel 1986; Tompa et al. 2014).

Moreover, some chemical characteristics of mineral sediments can be used as proxies for past changes in water chemistry and hydrological fluctuations (Guerra et al. 2015; Tompa et al. 2014). In particular, we will focus on the different distribution of $\mathrm{Mg}$ between silicate and carbonate phases during various hydrological regimes in the lake. 
This study focuses on the Trasimeno lake, which is a shallow and closed basin, with no natural outles, located in Central Italy. This lake has been subjected to severe water level fluctuations over the centuries (Ludovisi and Gaino 2010) as there is a close connection between the local precipitation/evaporation ratio $(\mathrm{P} / \mathrm{E})$ and the lake level. In addition, long-term reconstructions (up to 50,000 years BC) have recorded changes in the lake's water level, with alternating wet and dry phases, connected to climatic variations in the Mediterranean region (Francke et al. 2021; Marchegiano et al. 2019). Moreover, being a shallow lake, its sediments data interpretation is challenging because of re-lifting and mobilisation phenomena due to the low water depth and the wind action (Zohary and Ostrovsky 2011). This study aims at identifying the geochemical signature of the primary precipitation and deposition processes over the last 150 years in the Trasimeno lake, using high-resolution stratigraphic archives represented by sediment cores. To do this, we will combine chemical quantitative elemental analysis (ICPOES), semi-quantitative analysis of mineralogical composition (XRD), and SEM-EDS microanalysis. The main goal of the present work is the individuation and description of the main factors (anthropogenic, hydrological and biological ) driving and influencing the sedimentation process in the Trasimeno lake during the Anthropocene. The results obtained will put the necessary basis for successive works devoted to characterise trends of specific anthropic, organic and inorganic, proxies including stable isotopes.

\section{Materials and Methods}

\subsection{Study Site}

Trasimeno lake is a closed, shallow, and mesotrophic lake of naturalistic importance (Natura 2000 site, S.C.I., S.P.Z. and Regional Park (Ludovisi and Gaino 2010, Fig. 1). The lake covers an area of $124 \mathrm{~km}^{2}$, it has a maximum depth of $6 \mathrm{~m}$, and its bathymetry is very smooth. The catchment basin lies on a vast depression characterised by low permeability, covered by Plio-Pleistocene and Holocene deposits, of variable silicate to carbonate composition (Frondini et al. 2019). The basin comprises four different areas distinguished by lithology (for details see Fig. SM1 in Supplementary Material):

(1) The eastern area, between NNW (Borghetto) and S (right branch of the Rigo Maggiore (RM) stream), characterised by Cenozoic flyshioid sediments (sediments attributed to Macigno and Marnosa Arenacea), containing quartz, feldspars, phyllosilicates (such as muscovite, biotite and in variable amounts chlorite), and carbonates (such as calcite and dolomite) (Frondini et al. 2019);

(2) The area around the lake of Chiusi and near the basins of Moiano e Maranzano (MM) characterised by Pliocene coastal sediments, mainly consisting of sands with clayey fractions almost absent (Frondini et al. 2019);

(3) The western area between NNW (Borghetto) and SW (left branch of Anguillara channel) hosting the "Villafranchiano" fluvial-lacustrine alluvial deposits consists of sands and gravels interspersed with clayey levels (Frondini et al. 2019);

(4) Recent alluvial deposits surrounding the whole lake and consisting mainly of sands, silts, and numerous sharp clay intercalations (Frondini et al. 2019). 


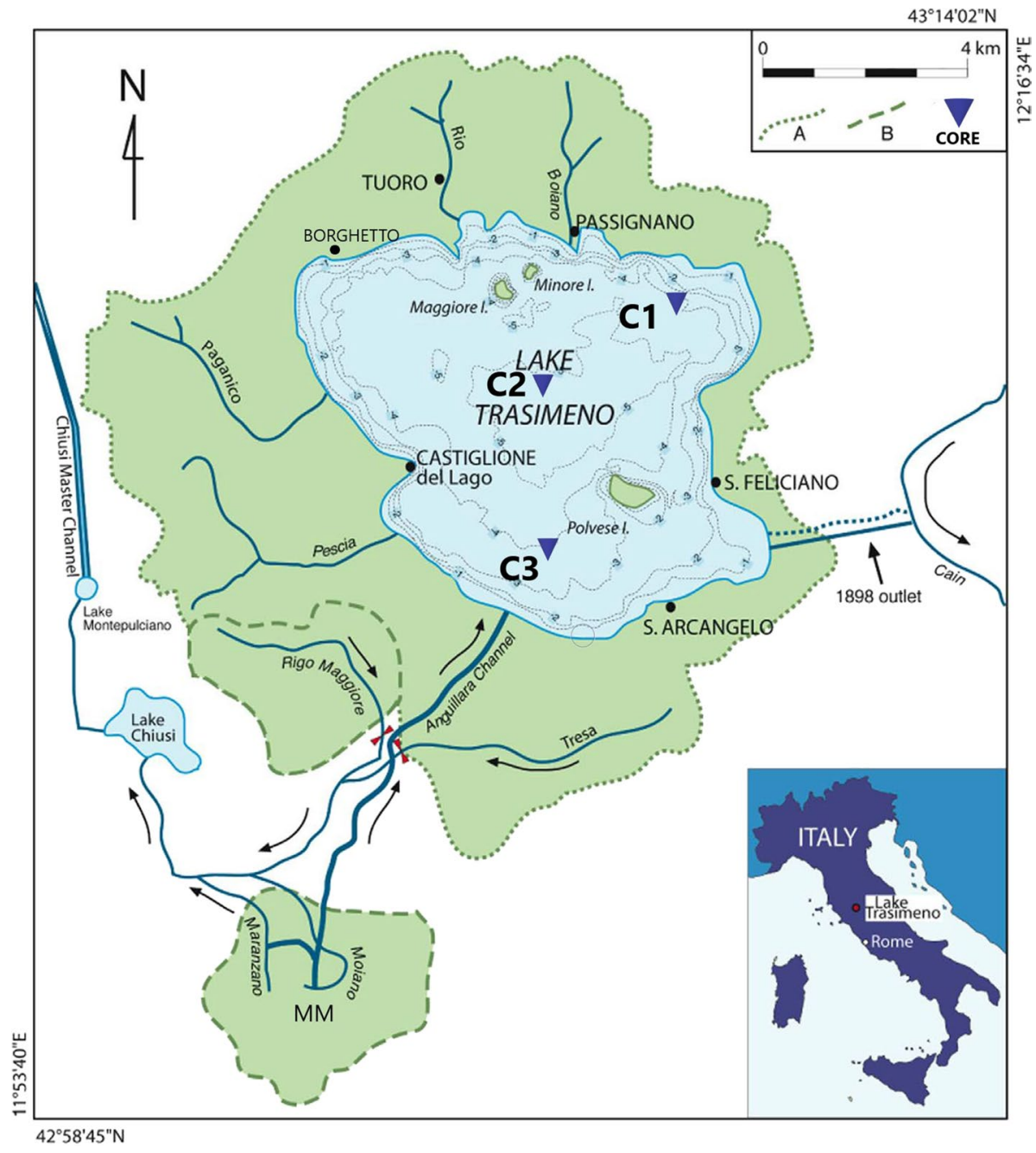

Fig. 1 a Map of Trasimeno lake with its catchment basin (modified from Marchegiano et al. (2018)), A) natural catchment area, B) artificially joined basins of Rigo Maggiore (RM) and Moiano and Maranzano (MM is joined to the lake by artificial canal crossing over the natural waterway). The blue triangles mark the location of sampling sites (C1,C2 and C3 cores located at the coordinates N 4309'40.0" E 1210'06.0", N 4308'38" E 1206'43" and N 4305'51" E 1206'38", respectively). In supplementary material Fig. SM1: b lithological scheme of the Trasimeno basin (modified from Martinelli (2012)), 1) Cenozoic flyschoid sediments (sediments attributed to Macigno and Marnosa Arenacea, 2) Pliocene coastal sediments, 3) "Villafranchiano" fluvial-lacustrine alluvial deposits, 4) recent alluvial deposits

The siliciclastic contributions are primarily from area 1), while the main calcareous-clayey contributions come from the other areas. The calcium carbonate component is high, while the contribution of dolomite is minimal.

The Trasimeno lake has no natural tributaries, and the surface catchment can be considered to coincide with the hydrological basin so that the rain falls directly on the lake. Therefore, the lake water balance is strongly affected by the pluviometric regime, and 
Fig. 2 Trend of depth water level evolution (modified from Ludovisi and Gaino (2010) and indicated by scatter line), with the three hydrological phases signed (Old, Middle, Young phases) subdivided on the basis of the two main anthropogenic interventions: (i) the modern construction of the outlets (shows by the horizontal line in 1898), (ii) the enlargement of the catchment basin (shows by the horizontal line in 1960). The dash line represents the hydrometric zero of Trasimeno lake. The graph shows the 3 stylised sediment cores (C1, C2, and C3). The individual sediment sections for each core are represented by the coloured squares (identification codes for each section are given in Fig. SM15 in the Supplementary Material). Each section as a function of the $y$-axis corresponds to the year obtained by dating of Gaino et al. (2012)

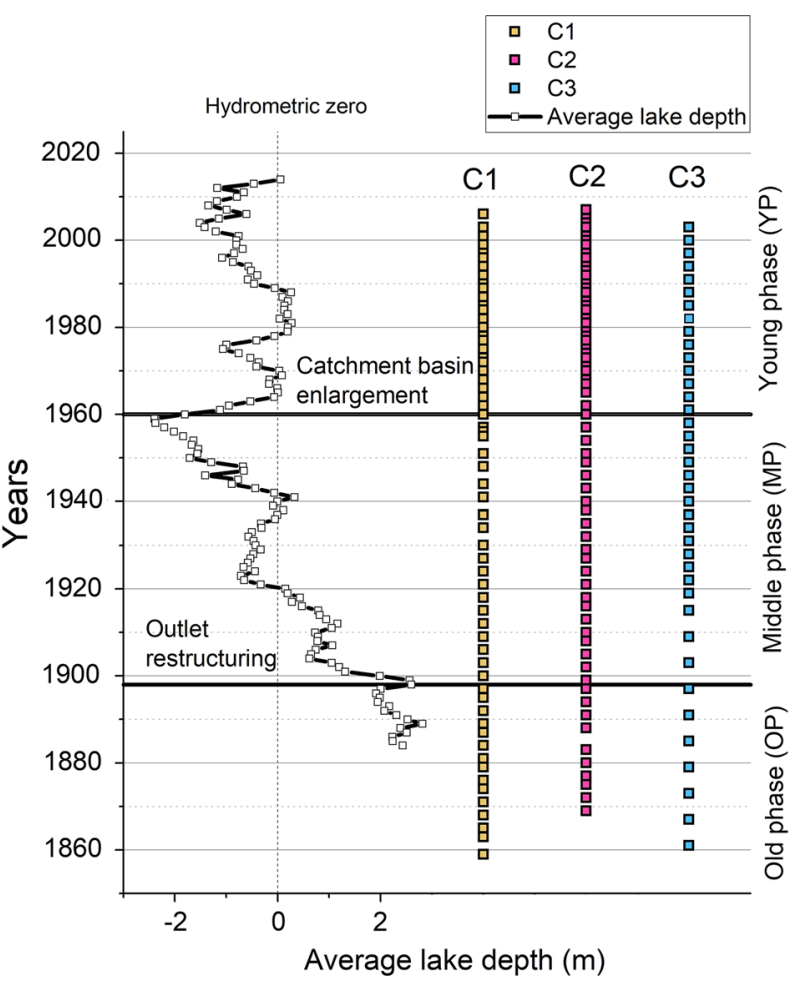

annual water inflows are frequently lower than evaporation losses. This strict dependence on the water balance with meteorological conditions caused dramatic floods and droughts over the centuries (Ludovisi and Gaino 2010. Human interventions have been made in order to regulate the lake level since Etruscan and Roman times. In particular, an artificial outlet was built in the medieval period (around 1420), which was inefficient to solve the water level fluctuations problem. At the end of the eighteenth century the water level increased again and in 1898 a modern outlet to the Tiber was built, parallel to the medieval one (Burzigotti et al. 2003; Dragoni 1982). As a consequence of this intervention, during the twentieth century the water level started to decrease, reaching the peak of a severe water crisis at the end of the 1950s (Ludovisi and Gaino 2010; Martinelli 2012).

The catchment area was artificially enlarged in the period 1957-1962, connecting the Tresa (T), Rigo Maggiore (RM), Moiano e Maranzano (MM) river basins to the lake by the Anguillara channel (Frondini et al. 2019) (Fig. 1)). Nevertheless, fluctuations of lake level persisted and were more evident during water crises that occurred in the next 50 years, most notably in 1970 and 1975 and between 1989 and 2012 (Martinelli 2012) .

In this study, we investigated the last 150 years of the Trasimeno lake's history. This period was subject to the two main man-made interventions, defined above, the modern outfall (1898) and the enlargement of the catchment area (1960s), both of which were carried out to solve the problems of fluctuating water levels, the droughts, and floods (Ludovisi and Gaino 2010). The period can be divided into three distinct phases, renamed as follows (Fig. 2): (i) a old phase (OP) (from 1860 to 1900), during which the water level exceeded the overflow level (257,5 $\mathrm{m}$ a.s.1.), allowing the discharge of suspended materials 
to the outside; (ii) a middle phase (MP) (from 1900 to 1960), during which the water level remained below the overflow level and also suffered a substantial lowering, causing saturation of the components in the water column; (iii) a young phase (YP) (from 1960 to 2010), during which the water level rose but not above the overflow level.

\subsection{Core Sampling and Preprocessing}

Three sediment cores C1, C2, C3 (Figs. 1 and 2), with depth below ground level of 95, 102, and $50 \mathrm{~cm}$, respectively, were sampled in May 2007 (Ludovisi and Gaino 2010) far from the trajectories of the "modern" naval routes. Each core was extruded and sectioned into a series of $1-\mathrm{cm}$ intervals for the uppermost $30 \mathrm{~cm}$ and into $2-\mathrm{cm}$ intervals for the lower remaining part. Radiometric measurements, performed on an aliquot of the samples, (Gaino et al. 2012), pointed to sedimentation rates of $0.21,0.20$ and $0.16 \mathrm{~g} \mathrm{~cm}^{-2}$ year $^{-1}$ for $\mathrm{C} 1, \mathrm{C} 2$, and $\mathrm{C} 3$, respectively, used to calculate the corresponding dating of the cores, by Gaino et al. (2012). The cores cover a period of 150 years from 1850 to 2007 (Fig. SM15). These sediment core sections were stored in freezers at $-20{ }^{\circ} \mathrm{C}$ at the University of Perugia (UNIPG). All samples were chemically analysed (using ICP-OES) in order to characterise the deposits and the entire basin in a uniform but detailed way. For the purposes of the present study (which is concerned with the sedimentary evolution of the whole basin), we focused on $\mathrm{C} 2$ core. The $\mathrm{C} 2$ core is located far from the shore of the basin and is less directly influenced by local sedimentary inputs and anthropogenic contributions. In addition, C2 core is also representative of the lake's depocentre, as evidenced by the higher sedimentation rate than the other cores and thus indicative of its general sedimentation trend. A small group of C2 core's samples, whose geochemical data showed some trends and/or peculiarities, was analysed by XRD and SEM to obtain clear and detailed information on the nature of the mineralogical phases involved in the sedimentary processes and thus on the sedimentary processes that occurred in the basin.

\subsection{Chemical Analysis}

We determined major and trace element (Al, Fe, Ti, Ca, Mg, K, P, and Mn; the wavelengths are reported in Table SM1 of the Supplementary Material) concentrations by inductively coupled plasma optical emission spectrometry (ICP-OES, Ultima 2, HORIBA Scientific) equipped with an ultrasonic nebuliser (CETAC Technologies, U-5000AT) after acid microwave digestion of the samples (modified protocol from method EPA 3050B (EPA 1996), performed by the Trace Elements Lab, Department of Chemistry, Biology and Biotechnology (DCBB)-UNIPG. The sediment samples for digestion procedure were thawed, homogenised, and air-dried, then ground in a porcelain mortar, and finally dried at $105^{\circ} \mathrm{C}$ for 24 h. An aliquot of $0.250 \mathrm{~g}$ of sediment was digested with $8 \mathrm{ml}$ of ultrapure $\mathrm{HNO}_{3}(65-69 \%)$ and $2 \mathrm{ml}$ of ultrapure solution of $\mathrm{H}_{2} \mathrm{O}_{2}$ (30-32\%). The digestion was performed in a Mars Microwave Oven, with two working steps: the first at $130{ }^{\circ} \mathrm{C}$ and 200 pound per square inch (psi) for 1 minute and the second at $180^{\circ} \mathrm{C}$ and 300 psi for 10 minutes. The digestion mixture was finally filtered using $2.5 \mu \mathrm{m}$ filters (Whatman Grade n42) and diluted to $50 \mathrm{~mL}$ with ultrapure $\mathrm{H}_{2} \mathrm{O}(18 \mathrm{M} \Omega)$.

Quality assurance was provided by determining the elemental concentrations for duplicate samples and soil reference material (Certified Reference material SS-1, Contaminated Soil). The recovery of total metal concentration varied between 79 and $130 \%$ among different analytes. The Limit of Detection (LOD) of the methods ranged from 
0.01 to $2.95 \mathrm{ppm}$ (Table SM2 and SM3 in the Supplementary Material). In addition, we determined the total organic matter (TVS\%) (in Fig. SM15) on a second portion of the same samples analysed in ICP-OES, by gravimetric measurements after incinerating an aliquot at $550{ }^{\circ} \mathrm{C}$ for 2 hours in a muffle furnace, of samples pre-dried at $105^{\circ} \mathrm{C}$.

\subsection{XRD and SEM Analysis}

X-ray powder diffraction (XRD) data collection was performed with a PANalytical X'Pert Pro diffractometer, PW3050 goniometer in Bragg-Brentano geometry, equipped with an $\mathrm{X}^{\prime}$ Celerator fast detector, using the Ni-filtered $\mathrm{Cu}-\mathrm{K} \alpha$ radiation $(40 \mathrm{kV}, 40 \mathrm{~mA})$, performed at the DCBB, UNIPG. Samples were ground in an agate mortar and carefully sideloaded onto a zero-background sample holder. Data were collected in the $4-80^{\circ} 2 \theta$ range using a $0.017^{\circ}$ step scan and $200 \mathrm{~s}$ counting time. All XRD patterns are reported and compared in Figs. SM2 and SM3. Qualitative phase analysis was performed by applying a search and match procedure with the help of the QualX program (Altomare et al. 2015) and the Crystallography Open Database (COD) (Gražulis et al. 2009). The presence of magnesium calcite phases, with formula $\mathrm{Ca}_{(1-x)} \mathrm{Mg}_{x} \mathrm{CO}_{3}$, was detected by the presence of anomalous broadening near the characteristic peaks of calcite phase (Fig. SM4). The $x$ value in the above formula was estimated by applying the dependence of the $2 \theta$ peak positions of the (104) reflections, at about $29^{\circ} 2 \theta$, on the $\mathrm{Mg}$ content. This dependence was obtained by interpolating the data reported in Zhang et al. (2010) (Fig. SM5); it resulted $x=0.353\left(2 \theta_{104}\right)-10.367(\mathrm{R}=0.999)$ in the $0-0.45 x$ range. Accurate (104) peak positions were estimated by the decomposition, and profile fit with pseudo-Voigt functions, of the cluster of peaks around $29^{\circ} 2 \theta$, using the Philips ProFit software (Figs. SM6 and SM7). Quantitative phase analysis of the crystalline fraction was carried out with the Rietveld method implemented in the GSAS program (Larson and Von Dreele 2001) using the crystalline phases previously identified. Figure SM8 shows the final Rietveld plot for some sample between C2-2 and C2-102. The $\mathrm{x}$ value of magnesium calcite phases was also estimated with the Rietveld method, by refining the $\mathrm{Ca}$ and $\mathrm{Mg}$ site occupancy factors. These two methods gave substantially similar results, with maximum discrepancies of 0.01 in the $\mathrm{x}$ value. Table in Fig SM9 reports the wt\% of crystalline phases of samples, while Table in Fig. SM11 reports the element contents, in $\mathrm{mg} / \mathrm{g}$, calculated from the Rietveld refinements, and compared with ICP-OES results.

Individual particle analyses were performed on selected samples by SEM coupled with energy-dispersive X-ray microanalysis (SEM-EDS), by LUNA LAB UNIPG. The samples were prepared by mounting a small aliquot of the sediment directly onto SEM aluminium stubs using double-sided carbon tape. The samples were finally coated with a $100-150-\AA$ carbon film to provide electrical conductivity and prevent charge buildup during the exposure to the electron beam. SEM imaging was performed using a ZEISS Supra 25 microscope equipped with a field emission gun and a GEMINI column employed at $15 \mathrm{kV}$ and variable magnification to distinguish particle types textural details. The instrument is also equipped with an X-ray-dispersive spectrometer (QUANTAX EDS microanalysis system coupled with ESPRIT software for data treatment). EDS spectra (spot size 5, working distance $7.7 \mathrm{~mm}$ ) were collected for $90 \mathrm{~s}$, and the elemental composition was obtained after standardless matrix correction provided by the ESPRIT software. Values lower than $0.1 \mathrm{wt} \%$ (SEM detection limit) were not considered. 
$\mathrm{C} 2-2$

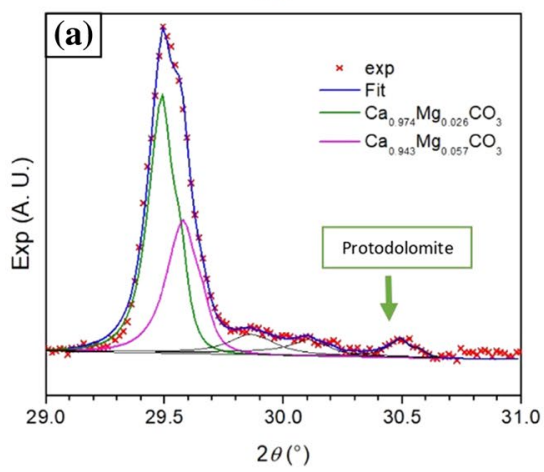

C2-94

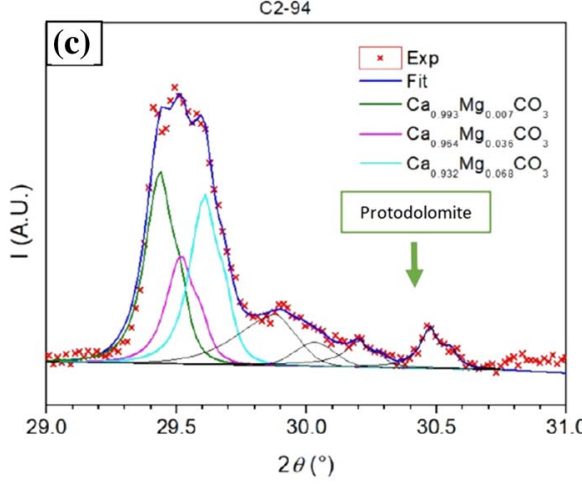

C2-44

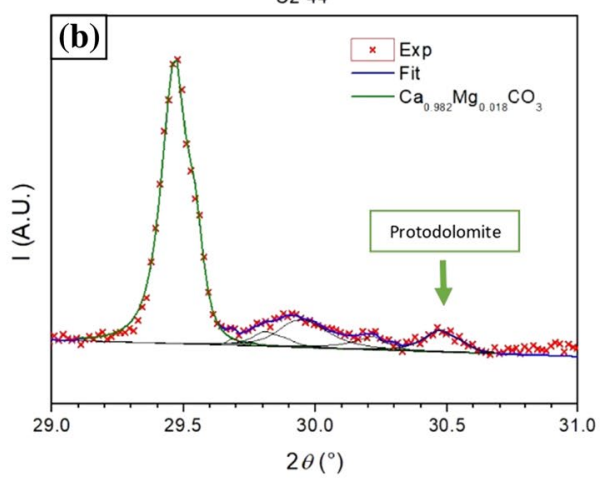

C2-102

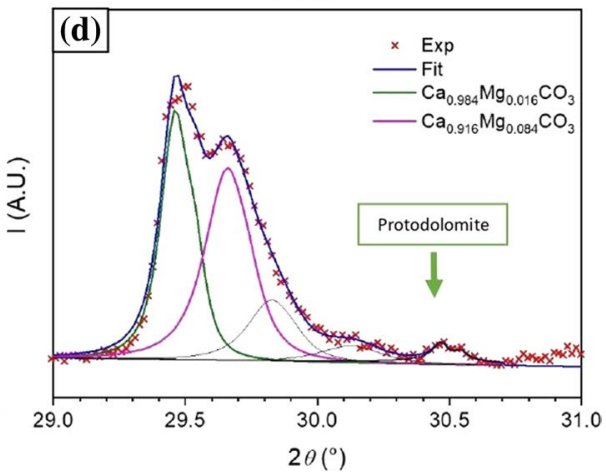

Fig. 3 Profile fitting of the (104) peak of calcite in which different components, associated with different $\mathrm{Mg}$ contents are shown. The estimated compositions of various phases, calculated on the basis of the linear regression of Fig. SM5, are also reported. Radiation: $\mathrm{CuK} \alpha$; fitting software: Philips Profit. Sample belonging to the phases YP (sample named C2-2 in panel a); MP (sample named C2-44 in panel b); OP (samples named C2-94 and C2-102 in panels $\mathbf{c}$ and d)

\section{Results}

\subsection{Mineralogy and Phase Analysis}

The small group of samples analysed by XRD showed similar spectra indicating similar types and quantities of the mineral phases presents. Quartz, calcite, Mg-calcite, albite, chamosite, and phengite were found in all the analysed samples. Protodolomite, a metastable phase of composition similar to dolomite, was also identified, as a small peak at ca. $30.5 \AA$ in all samples (Fig. 3) previously identified by Tompa et al. (2014). Pyrite was found exclusively in the samples from the OP and bottom part of the MP phases. All experimentally identified crystalline phases, reported above, were used for quantitative analysis, with the exception of protodolomite, due to its low intensity.

The wt $\%$ of quartz and phengite are similar for all samples, amounting 18.9-22.9\% and $43-48 \%$ of the crystalline mass, respectively. Old samples have a higher proportion of chamosite and albite (18-19\% and 9.9-10.3\%, respectively) than young samples (14-16\% and $8-7 \%$, respectively). The maximum amount of pyrite was found at the bottom of core $\mathrm{C} 2$ with a $1.3 \%$ of the total mass (details in the table in Fig. SM9). 
All samples contain one, two, or even three Mg-calcite phases with formula $\mathrm{Ca}_{(1-x)} \mathrm{Mg}_{x} \mathrm{CO}_{3}$ in which $\mathrm{x}$ was found to change from 0 to 0.084 (Table in Fig. SM9 and Figs. SM4, SM6 and SM7). The middle samples (MP) (shown in Fig 3b) mainly contain calcite with a low Mg content (x from 0.017 to 0.025 ) while the old (OP) (shown in Fig. 3c, d) and young samples (YP) (shown in Fig. 3a) contain two or three Mg-calcite phases (x from 0 to 0.084 ). Figure 3 shows the decomposition of the (104) peak of calcite phases of samples from old, middle and young part of Core $\mathrm{C} 2$, in which the composition of various components, estimated on the basis of $2 \theta$ peak position, is also reported.

Table in Fig. SM10 reports the chemical compositions of crystalline phases adopted for Rietveld refinements. From the quantitative phase analysis and the chemical compositions of different phases, it was possible to estimate the content of various elements in the samples, which is reported in Table in Fig. SM11, and compared with the ICP-OES results. In comparing these two datasets, we must take into account the natural variability of the compositions of phengite, albite and chamosite, which generally do not lead to large differences in their XRD patterns. This means that the phases contained in the actual samples may have slightly different compositions than those chosen for the Rietveld refinement procedure. However, by direct experimentation it is very difficult, if not impossible, to accurately determine the real composition of each crystalline phase in these complex samples. This may justify the discrepancies observed between the Rietveld refinement data and those from ICP-OES. Notwithstanding, the two sets are in good agreement in most of samples and elements. This global agreement lets to assume that these samples contain a relatively small amount of amorphous phase that could be responsible of the small amount of phosphorus found by ICP-OES analysis.

\subsection{Geochemistry and Mineral Chemistry}

Major and trace element concentrations in the three cores are reported in Tables SM4, SM5, SM6, SM7, SM8, and SM9 of Supplementary Material. The trends of representative major and trace elements in the cores are reported in Fig. 4. In the graph, data are normalised to $\mathrm{Al}$ to provide information on the type/relative abundance of the alumino-silicatic (sheet minerals, feldspars) and the non-silicatic (carbonates, sulphides, phosphates) fractions within the sediment.

$\mathrm{Fe}, \mathrm{Mn}$, and P reveal similar trends in the cores (Fig. 4a). In particular, Fe remains fairly stable while $\mathrm{Mn}$ and $\mathrm{P}$ tend to increase. Decreasing trends of $\mathrm{Mn}$ and $\mathrm{P}$ are also found in C3 during OP. As regards Fe, the observed trend can be explained by the persistence of the contributions of the Fe-bearing phyllosilicates clinochlore and phengite over the entire period. Regarding $\mathrm{P}$ and $\mathrm{Mn}$, instead, nothing can be said just looking at the mineralogical composition due to the low concentrations of these elements as a vicariant ion in the carbonate and silicate fraction (Mn), and a main constituent of accessory phosphates (P), respectively.

The decreasing trend of $\mathrm{Mn} / \mathrm{Al}$ and $\mathrm{P} / \mathrm{Al}$ ratios during $\mathrm{OP}$ is somehow puzzling. Given the lower sedimentation rate at $\mathrm{C} 3$ compared to $\mathrm{C} 1$ and $\mathrm{C} 2$ sampling sites, this fact can be explained with the presence of peculiar hydrodynamic conditions (e.g. water fluxes by local inputs and currents) leading to (i) selective deposition of coarser-grained sediments of different composition and/or (ii) reduced extent of chemical precipitation of phosphate and, secondly, carbonate minerals from the water column. In order to test this hypothesis, in Fig. 5 the trends of $\mathrm{P}$ concentration and $\mathrm{Mn} / \mathrm{Fe}$ ratio in respect to TVS\% in C2 have been reported and compared. It is observed that TVS\% and the Mn/ 

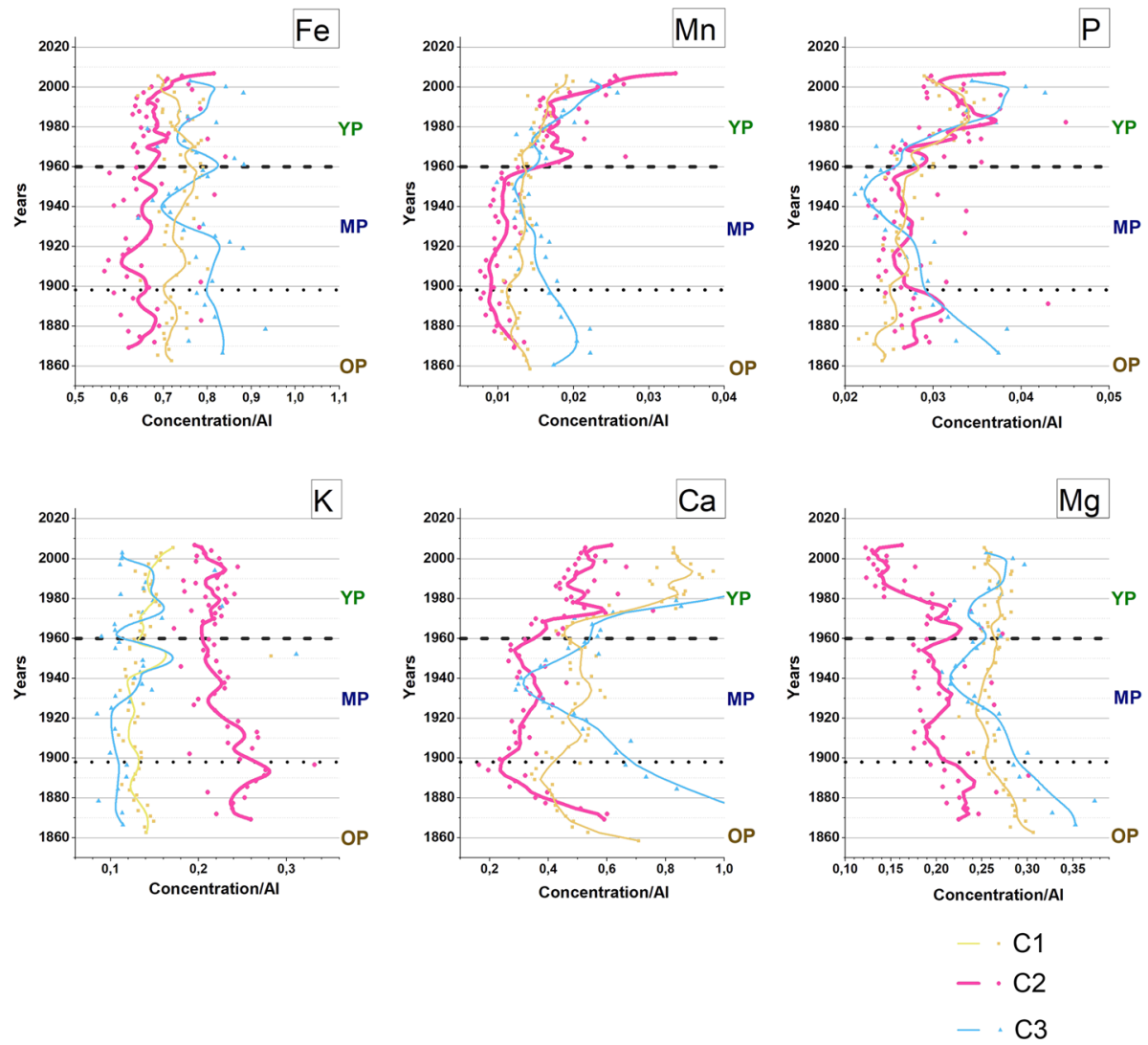

Fig. 4 The trend of normalised aluminium concentrations (adjacent-averaging method, with weighted average options being used on 5 points to obtain the trends) of major and trace elements (mg/g), measured by ICP-OES, in the three sediment cores (C1 (yellow squares and line), C2 (pink circles and line), C3 (blue triangles and line)), is reported. The characteristic hydrological phases of the lake are shown (Old phase (OP), Middle phase (MP), and Young phase (YP)) on the time scale: the construction of the modern outlet in 1898 is shown by a dotted line, while the enlargement of the catchment area is shown by a dashed line

Fe ratio decreased during the OP, TVS\% was continuing to decrease until 1920 while $\mathrm{Mn} / \mathrm{Fe}$ ratio was stable during the MP and finally both increased in the YP. P remained roughly stable with little fluctuation during OP and MP; it increased during YP reaching a peak value in the early 1980s and decreased afterward. These features suggest the possible correlation between the accumulation of organic matter (probably indicating the presence of primary producers) and the establishment of oxidation environmental conditions favourable to the precipitation of phosphates and metal oxides (Naeher et al. 2013). Moreover, the observed decreasing trends of $\mathrm{Mn} / \mathrm{Al}$ and $\mathrm{P} / \mathrm{Al}$ ratios in $\mathrm{C} 3$ during OP can, thus, be explained with the occurrence of pulses of freshwater inputs at higher hydrodynamic regime. The precipitation of phosphates in the P-enriched samples was, actually, evidenced in C2 during YP. There, in fact, the SEM-EDS spot analyses performed on the sediment aggregates revealed the presence of a few isolated P-bearing grains whose shape (regular, pseudo-hexagonal) and composition ( $\mathrm{Ca}: \mathrm{P}$ atomic ratio is 3:1) are compatible with those of hydroxyapatite (Fig.6). 
Fig. 5 Trends (trends line were obtained using the adjacentaveraging method, with weighted average options using 5 points) of TVS\% (dark green), $\mathrm{Mn} / \mathrm{Fe}$ (light green), P (blue) in the core $\mathrm{C} 2$. The two main human interventions and the subdivisions into the 3 main hydrological phases (Old (OP) middle (MP) and young (YP) phases) are also shown in the graph

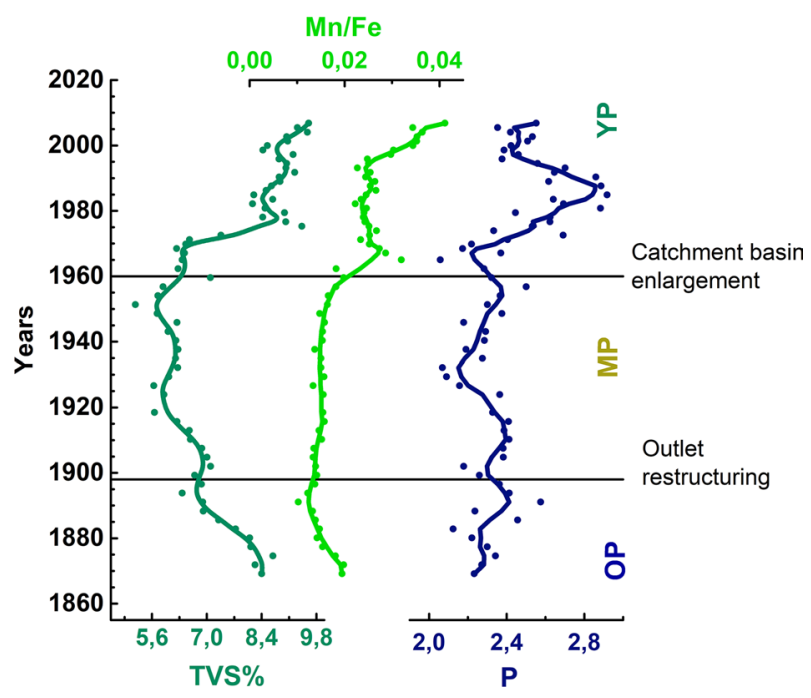

$\mathrm{K}, \mathrm{Ca}$, and $\mathrm{Mg}$ reveal distinct trends in the cores (Fig. $4 \mathrm{~b}$ ). In the core $\mathrm{C} 2$, the $\mathrm{K} / \mathrm{Al}$ ratio shows a decreasing trend in $\mathrm{OP}$ and $\mathrm{MP}$ followed by a phase of relative stability. In the cores $\mathrm{C} 1$ and $\mathrm{C} 3$, instead, the K/A1 values remain stable or increase slightly during MP and/or YP. Looking at the mineralogical composition of C2, these differences can be easily explained assuming different contributions of phengite mica within the sediment. In particular, since K shows a good correlation with Al (Fig. SM13 in Supplementary Material) and is mostly contained in mica, the approximately double values of the $\mathrm{K} / \mathrm{Al}$ ratio in $\mathrm{C} 2$ compared to $\mathrm{C} 1$ and $\mathrm{C} 3$ reveal a much greater contribution by phengite at the depocentre rather than on the shores of the lake.

$\mathrm{Ca}$ and $\mathrm{Mg}$ show even more distinct trends from each other in the three cores. In $\mathrm{C} 1$ and $\mathrm{C} 2$, the $\mathrm{Ca} / \mathrm{Al}$ ratio drops in $\mathrm{OP}$; it undergoes high fluctuations in $\mathrm{MP}$, with a general increasing trend to 0.4-0.6, and shows a final increase after 1970 (YP). In C3, the drop and the increase in the $\mathrm{Ca} / \mathrm{Al}$ ratio are much more intense for approximately double values of the ratio at the bottom (OP) and the top (YP) of the sedimentary sequence. Regarding $\mathrm{Mg}$, a decrease in the $\mathrm{Mg} / \mathrm{Al}$ ratio is still observed during OP, but this mainly occurs in cores $\mathrm{C} 1$ and $\mathrm{C} 3$ while in $\mathrm{C} 2$ it only occurs from the end of the OP phase to the first half of the MP phase. The values of the $\mathrm{Mg} / \mathrm{Al}$ ratio tend to stabilise, though fluctuating, during MP and YP in $\mathrm{C} 1$ and $\mathrm{C} 3$, and decrease significantly during $\mathrm{YP}$ in the case of $\mathrm{C} 2$. Ca and $\mathrm{Al}$ show a weak anticorrelation $\left(R^{2}=-0.24\right)$, and data are very scattered (Fig. SM12 in Supplementary Material), suggesting significant calcium carbonate amounts in all the sediments. The overall correlation between $\mathrm{Mg}$ and $\mathrm{Al}$ for all samples (Fig. SM14 in Supplementary Material) is low $\left(R^{2}=0.34\right)$, indicating that $\mathrm{Mg}$ is associated with both silicate and carbonate phases. Detailed analysis of the correlation between $\mathrm{Ca}$ and $\mathrm{Mg}$ in the $\mathrm{C} 2$ core reveals three different correlation patterns, each related to a distinct hydrologic phase (Fig. 7). Namely, the correlation is positive and weak $\left(R^{2}=0.52\right)$ during OP, it is negative and weak during MP $\left(\mathrm{R}^{2}=-0.49\right)$, with greater slope and a more dispersed dataset especially at lower $\mathrm{Ca}$ concentrations, and negative and even higher during YP $\left(R^{2}=-0.69\right)$ with a more pronounced slope. This fact points to different compositions of the $\mathrm{Mg}$ - $\mathrm{Ca}$ carbonate fraction in the three hydrological phases. 

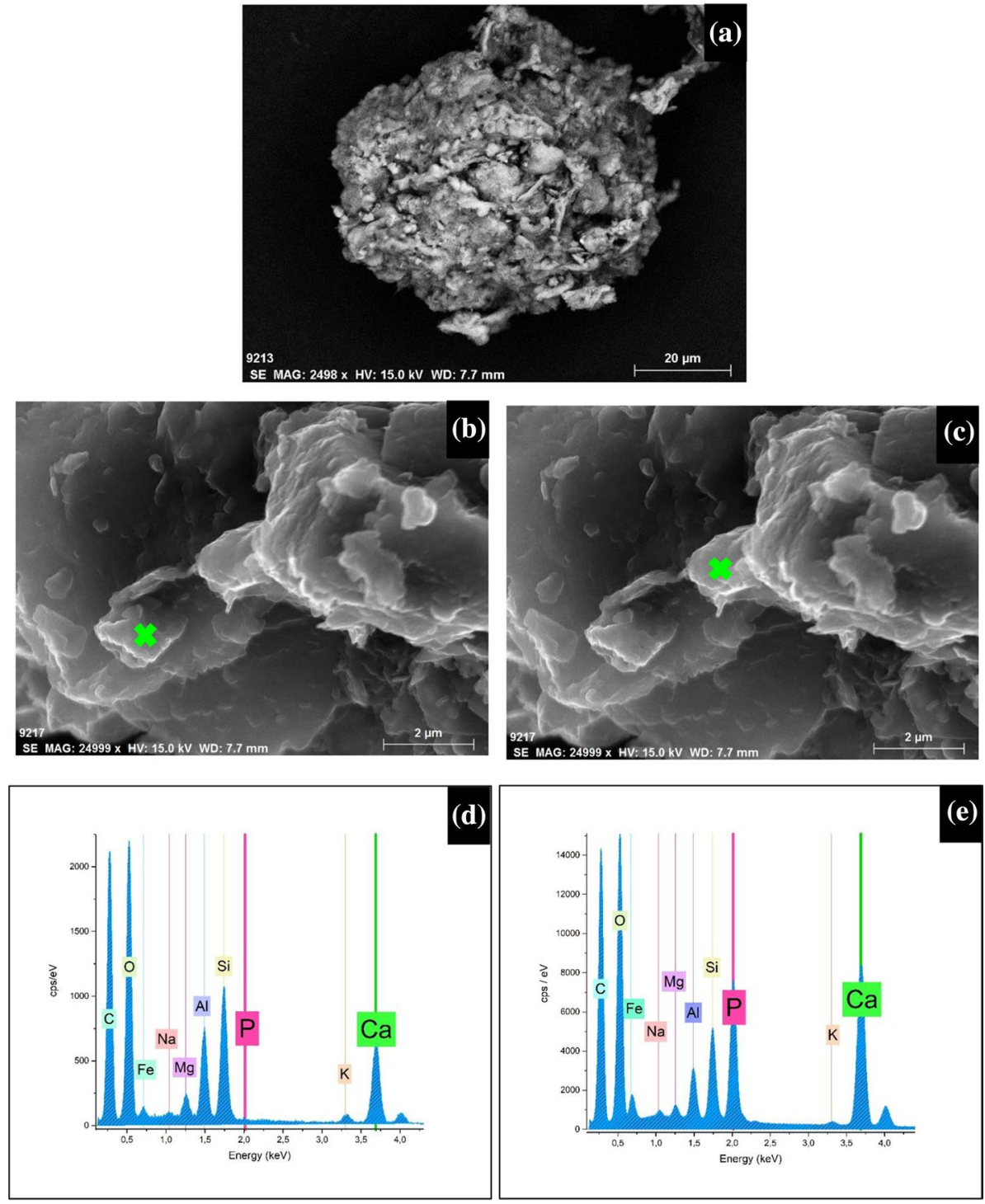

Fig. 6 SEM micrographs of a sediment aggregate a with a phosphate grain (c, e) surrounded by silicate/ carbonate grains $(\mathbf{b}, \mathbf{d})$. The green crosses mark the spot analysis

\section{Discussion}

\subsection{Endogenic Precipitation Processes}

The mineralogical composition of the sediments of the Trasimeno lake varied along with OP, MP, and YP hydrological phases. As a first goal of the present study, we aimed at investigating the evolution over time of the sediments' carbonate and silicate nature. This objective has been achieved by exploiting specific indicator ratio trends (Fig. 4b) and correlation 
Fig. 7 Plot Ca vs. Mg of the samples from core $\mathrm{C} 2$ distinguished by hydrological phase (OP, MP, and YP). For each sample group related to a different hydrological phase, a trend line was obtained by means of a linear fitting

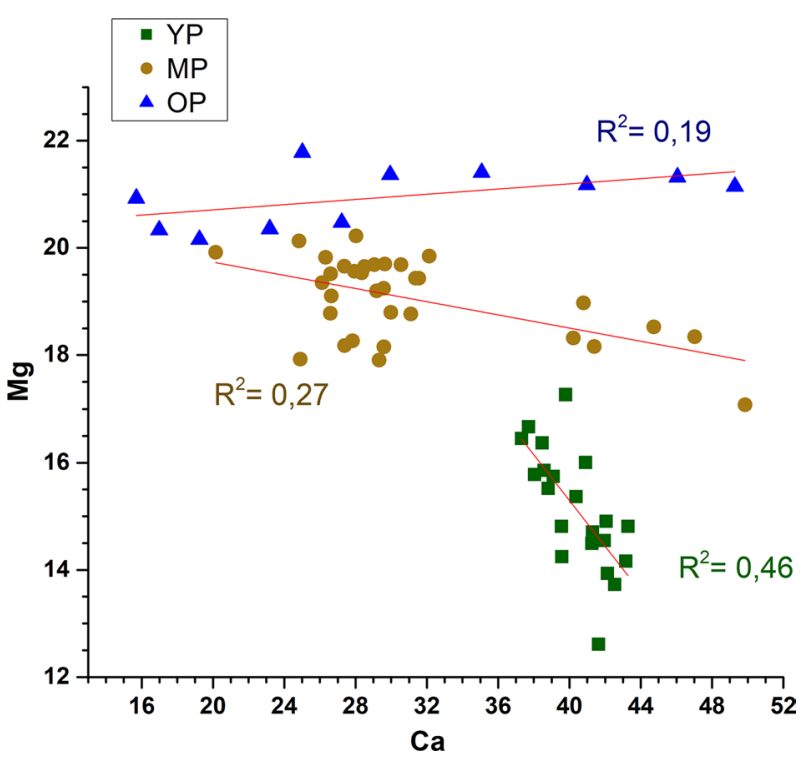

(Fig. 7 and Figs. SM12, SM13, SM14). As shown above, the Ca/Al ratio (Fig. 4b) presented a characteristic trend, with a sudden drop during the OP phase, in agreement with the water level trend. The ratio was stable during the MP, while it had a gradual growth stabilising at higher values at the beginning of YP. Higher values of this ratio indicate an increase in carbonate amount as compared with silicates. The $\mathrm{Ca} / \mathrm{Al}$ increase does not necessarily indicate more endogenic precipitated carbonates within the water column because the carbonates can also come from physical processes of erosion, transport, and deposition of the material from the catchment basin, even if the lake lacks major tributaries as it is closed. As a first conclusion, it can be deduced that the sedimentation conditions present in $\mathrm{OP}$ and EP were not equivalent. The presence of silicates in the lake sediment was assessed by the $\mathrm{Mg} / \mathrm{Al}$ and $\mathrm{K} / \mathrm{Al}$ ratios. The XRD results on phengite, albite, and chamosite suggest that the amount of $\mathrm{K}$ in the aluminosilicate phases does not change, through different hydrologic phases; this results from the absence of particular densification in the K-Al correlation graph (Fig. SM13) and the constant presence of phengite in all the investigated samples. We note that $\mathrm{Mg}$ is also present in silicate phengite, but unlike $\mathrm{K}$, it does not have a reasonable correlation with $\mathrm{Al}\left(R^{2}=0.34\right)$. The results of the $\mathrm{Mg}$ - $\mathrm{Al}$ correlation (Fig. SM14) suggest that Mg splits between different phases, in silicate phases as well as in other phases.

The distinction between the three hydrological phases is apparent in the correlation between $\mathrm{Ca}$ and $\mathrm{Mg}$ (Fig. 7), which points towards different sedimentation phenomena in the three phases. During OP, calcite stably contains $\mathrm{Mg}$ as a substitute for $\mathrm{Ca}$ with a replacement in the 0-8.4\% range, as indicated by the XRD measurements (table in Fig SM9 in Supplementary Material). The correlation for OP phase is opposite than for MP ( $R^{2}=0.52$ and $R^{2}=-0.49$ ). Furthermore, the MP's samples are divided into a first set in which silicates accompany the carbonates and a second set closer to the EP phase samples. We remember that the EP was characterised by a carbonates' growth trend accompanied by a decreasing silicates trend correlated with water thinning, as a result of strong water fluctuations due mainly to anthropogenic interventions. We found a strong negative correlation 
between $\mathrm{Ca}$ and $\mathrm{Mg}$ during the YP phase, which indicates a decrease in $\mathrm{Mg}$ contained in carbonates, compared to OP. The $\mathrm{Mg}$-Ca correlation explains the presence of mixtures of carbonate and silicate phases; in fact our results point to the presence of mixtures of $\mathrm{Mg}$ calcite, calcite, and phengite phases.

Overall, these proxies indicate that the carbonate materials have undergone considerable variations compared to the silicate material, which has remained almost unchanged. Siliciclastic materials are mainly represented by clastic material, both related to river activity and slopes washing. Silicate compounds are not formed directly from the phenomena that occur in the water column (Zolitschka et al. 2015). On the other hand, carbonate species are represented both by clastic, biogenic, and endogenic components. Ca be strongly related to them. Therefore, the study of $\mathrm{Ca}$ 's complex pattern in Trasimeno sediments allowed the understanding of the variations in sedimentary processes.

From Rietveld refinement data, it was possible to calculate the $\mathrm{Ca}$ content in $\mathrm{mg} / \mathrm{g}$ referred to the crystalline fraction of samples only. The global trend reproduces well the variation in Ca content obtained by the ICP-OES measurements, although the absolute values taken from Rietveld are generally lower (up to 20\%) than ICP-OES data, especially for MP samples (between C2-30 and C2-86). Therefore, we hypothesise that, during OP and $\mathrm{YP}, \mathrm{Ca}$ is distributed among different mineralogical phases, including those most commonly present in the sediments: pure calcite, $\mathrm{Mg}$-calcite, dolomite and prodolomite, aragonite, and especially amorphous phases, which are richer in Ca than the crystalline fraction.

The ratio between $\mathrm{Mg}$ and Ca concentrations from ICP-OES suggests a possible condition for Dolomite (Do), but, instead, the XRD analysis does not detect Do in the sediments samples. Indeed, the formation of Do mineral is very difficult because of the precise $\mathrm{Ca}-\mathrm{Mg}$ ordering (Goldsmith and Graf 1958) and for the need of temperature and pressure conditions typical of modern sedimentary environments (Tompa et al. 2014; Sánchez-Román et al. 2011); moreover, the crystallisation of Do is difficult if the process is too fast and if there is high concentration of competing ions (Robert and Land 1975). This constitutes the heart of the "dolomite problem" (Holland and Zimmermann 2000).

From ICP-OES data, the \% of Mg has varied during OP, MP, and YP, ranging from about $21 \mathrm{mg} / \mathrm{g}$ in the OP to about $14 \mathrm{mg} / \mathrm{g}$ in the YP (Table in Fig. SM11 in supplementary material). Rietveld data are in globally agreement with the ICP-OES data, although there are differences mainly for younger samples, where the Rietveld data present excess amounts of Mg compared to the ICP-OES. The difference between Rietveld and ICP-OES data can be explained by the choice of crystalline phases for Rietveld refinement, which do not match perfectly with the phases contained in the actual samples. From the decomposition of the XRD spectra, it is also evident the presence of a small peak at $30.5 \AA$ which can be ascribed to a small amount protodolomite (Pr) (Fig. 3). Pr is considered a semicrystalline precursor of dolomite and is a metastable phase with a dolomite-like composition along with a completely disordered arrangement of $\mathrm{Ca}$ and $\mathrm{Mg}$ in its structure (Tompa et al. 2014; Liu et al. 2020; Müller 1970; Last 1982). The relative amount of Pr could not be estimated by the XRD analysis; however, the very low intensity of this peak in all samples indicates that its value is negligible. $\mathrm{CaCO}_{3}$ minerals are usually formed in the water of Trasimeno lake, especially under evaporation conditions and in the presence of high concentrations of $\mathrm{Ca}, \mathrm{Mg}$, and $\mathrm{CO}_{3}^{=}$ions (Solotchina and Solotchin 2014). Minerals such as $\mathrm{Mg}$-calcite and Protodolomite, with disordered arrangement of $\mathrm{Mg}$ atoms, are particularly favoured (Robert and Land 1975). Due to Mg's random substitutions in the calcite structure, these phases are metastable and can recrystallise into a more stable form like dolomite (Althoff 1977), although crystalline dolomite was not detected in our samples. The combination of Mg-calcite and calcite can represent well all the phases containing calcium during 
OP. During the YP, on the other side, P-bearing micrometric grains with pseudo-hexagonal shape and composition similar to apatite $(\mathrm{Ca}: \mathrm{P}=3: 1)$ were clearly detected by SEM-EDS as shown in Fig. 6. This pseudo-regular shape suggests a crystal formed directly within the water column, while a rounded, blunt shape would have indicated a grain from the outflow of the basin. What characterises YP compared with the other phases OP and MP is the presence of an evident eutrophication, due to an excessive load of phosphorus (and other nutrients), coming both from external loads wastewater treatment plants and from uncontrolled discharged, and internal load, i.e. immediate release from the lake sediments themselves towards the overlying water (Ribeiro et al. 2008).

According to (Naeher et al. 2013), a decrease in the Mn/Fe ratio in the sediments, as observed in the OP phase of our data (Fig. 5), indicates a reduction in primary/global production and reduction in bottom-water oxygenation. Instead, an increase in the $\mathrm{Mn} / \mathrm{Fe}$ ratio as observed in the YP (Fig. 5) reflects a larger supply of nutrients within the lake, likely coming from the watershed, leading to increased microorganisms' growth. Studies carried out on the populations of microorganisms present in the water of Trasimeno (Martinelli 2012) have made it possible to learn that phytoplankton is the predominant species among primary producers and is in excess compared to primary consumers, such as zooplankton, since the 1970s. Confirmatory measurements of the ratio between isotopes of ${ }^{13} \mathrm{C}$ and ${ }^{15} N$ (Della Bella 2019) showed that most of the organic matter present during YP in the Trasimeno sediments is represented by primary producer species, such as phytoplankton (Della Bella 2019). The influence of phytoplankton on the oxygenation of bottom water is reflected in the strong increase in $\mathrm{Mn} / \mathrm{Fe}$ during YP (Fig. 5), indicating the high amount of autotrophic microorganisms and greater oxygenation during this period.

Therefore, we suppose that the Mg-calcite precipitation could have been triggered by the high levels of phytoplankton productivity which determined supersaturated conditions (Last 1982). The co-precipitation processes follow unclear mechanisms but are usually triggered by the uptake of $\mathrm{CO}_{2}$ or $\mathrm{HCO}_{3}^{-}$by phytoplankton (or by other photosynthetic plants) and increase in $\mathrm{pH}$, resulting in supersaturation in calcite. In Trasimeno lake, the $\mathrm{pH}$ values can undergo significant seasonal variations (Martinelli 2012), especially in spring-summer it can reach maximums around 10. Therefore, it could have been an ideal situation for the co-precipitation phenomenon. The detection of these P-bearing micrometric grains was not confirmed by XRD investigations, probably due to their low crystallinity or because the amount of this phase is under the limit of detection of the technique.

This piece of information confirms that in the Trasimeno sediments, there are also noncrystalline compounds, commonly found in clayey materials. These compounds are probably mixed crystal or surface complexes of phosphorus which are kinetically favoured over crystalline compounds, such as apatites (Avnimelech 1980, 1983). In the waters of Trasimeno, dissolved $\mathrm{P}$ can be incorporated in active sites of the crystal structures during their growth (Hartley et al. 1997) or can be absorbed on $\mathrm{CaCO}_{3}$ structure forming an amorphous calcium carbonate phosphate $(\mathrm{CaPC})$ or surface complexes, which could then be transformed into crystalline apatite over time (Stumm and Leckie 1971). This process confirms the strong negative correlation during YP between $\mathrm{Mg}$ and $\mathrm{Ca}$ (Fig. 7), as the precipitated $\mathrm{Mg}$ drops dramatically to make room for $\mathrm{P}$ in the calcite carbonates.

Based on the biomass data collected and through estimates of the nutrient loads spilled into the lake from sewers, purification plants, livestock discharges, and leaching of cultivated land, portraying the YP period, the condition of the Trasimeo lake passed from mesotrophic to eutrophic (Giovanardi et al. 1995; Cingolani and Charavgis 2004). Despite the high annual spills of nutrients, low concentration of P (less than $1 \mu g / L)$ in the water column was found (Ludovisi and Gaino 2010; Martinelli 2012; Morozzi 1996), confirming 
that phosphorus must be present in an insoluble form within the sediments. The absence of $\mathrm{P}$ in the water masked the state of eutrophication that the lake has undergone since the 1970s.

Previous studies Viotti (2014), based on P sequential extractions, performed on superficial sediments of Trasimeno, found that $\mathrm{P}$ is mainly adsorbed as $\mathrm{HCl}-\mathrm{P}$ (represents $\mathrm{Ca}$ bound $\mathrm{P}$, including organic phosphorus and phosphorus forms that are sensitive to low $\mathrm{pH}$ such as apatite). Therefore, the co-precipitation process with $\mathrm{CaCO}_{3}$ is considered an important contribution to the $\mathrm{P}$ flow towards sediments. It is possible to confirm that the endogenic $\mathrm{P}$ precipitations triggered inside the water column, which lead to high $\mathrm{P}$ concentrations in the sediment during YP, are more likely than detrital $\mathrm{P}$ transported by the catchment area's runoff.

\section{Conclusion}

The high sensitivity of the closed, shallow Trasimeno lake to water level fluctuations made this lacustrine ecosystem highly prone to variations in precipitation and sedimentation processes, especially during the three major hydrological phases (OP, MP, and YP) of the last 150 years. The present detailed study of high-resolution stratigraphic archives made it possible to characterise these phases through a detailed mineralogical and geochemical analyses of the sediments.

The Trasimeno lake sediment records showed an alternation between wetter periods (e.g. as during OP), water crises indicating drier periods (e.g. at the end of MP), with transition periods between them. The endogenic carbonate compounds contained different amounts of $\mathrm{Mg}$ during different hydrologic periods. Lake sediments were particularly rich in Mg-calcite compounds over the OP and YP but with different compositions due to either the hydrologic and biological effects. Amorphous calcium carbonate phosphate (CaPC) precipitates (or surface complexes) containing high quantities of $\mathrm{Ca}$ and $\mathrm{P}$ have been identified in the lake sediments during the YP. The precipitation of these surface complexes was triggered by the growing of $\mathrm{P}$ loading inside the lake, though the exact process of formation and current nature of the precipitated species have not been established.

The results of this study will put the necessary basis for successive studies devoted to characterise trends of specific anthropic proxies. Special interest will be also paid to develop predictive models of the effects of environmental changes. Shallow lakes like Trasimeno are, in fact, highly susceptible to hydrologic fluctuations due to the impact of climate change and human activities. In this respect, it will be necessary to manage and optimise human interventions to be carried out to keep these basins as undisturbed as possible.

Supplementary Information The online version contains supplementary material available at https://doi. org/10.1007/s10498-022-09403-y.

Open Access This article is licensed under a Creative Commons Attribution 4.0 International License, which permits use, sharing, adaptation, distribution and reproduction in any medium or format, as long as you give appropriate credit to the original author(s) and the source, provide a link to the Creative Commons licence, and indicate if changes were made. The images or other third party material in this article are included in the article's Creative Commons licence, unless indicated otherwise in a credit line to the material. If material is not included in the article's Creative Commons licence and your intended use is not 
permitted by statutory regulation or exceeds the permitted use, you will need to obtain permission directly from the copyright holder. To view a copy of this licence, visit http://creativecommons.org/licenses/by/4.0/.

\section{References}

Althoff PL (1977) Structural refinements of dolomite and a magnesian calcite and implications for dolomite formation in the marine environment. American Mineral 62(7-8):772-783

Altomare A, Corriero N, Cuocci C, Falcicchio A, Moliterni A, Rizzi R (2015) QUALX2.0 : a qualitative phase analysis software using the freely available database POW_COD. J Appl Crystallogr 48(2):598-603. https://doi.org/10.1107/S1600576715002319 (ISSN 1600-5767)

Avnimelech Y (1980) Calcium-carbonate-phosphate surface complex in calcareous systems. Nature 288(5788):255-257, 1476-4687. https://doi.org/10.1038/288255a0,ISSN 0028-0836

Avnimelech Y (1983) Phosphorus and calcium carbonate solubilities in Lake Kinneret: $\mathrm{P}$ and $\mathrm{CaCO}_{3}$ solubility. Limnol Oceanogr 28(4):640-645. https://doi.org/10.4319/lo.1983.28.4.0640 (ISSN 00243590)

Burzigotti R, Dragoni Walter, Gervasi L, Evangelisti C (2003) The role of Lake Trasimeno (central Italy) in the history of hydrology and water management. In: IWHA 3rd international conference, Epypt

Cingolani L, Charavgis F (2004) Monitoraggio qualitativo dei corsi d'acqua superficiali individuati nel piano stralcio per il lago Trasimeno

Corella JP, Stefanova V, El Anjoumi A, Rico E, Giralt S, Moreno A, Plata-Montero A, Valero-Garcés BL (2013) A 2500-year multi-proxy reconstruction of climate change and human activities in northern Spain: the Lake Arreo record. Palaeogeogr Palaeoclimatol Palaeoecol 386:555-568. https://doi.org/ 10.1016/j.palaeo.2013.06.022

Damnati B, Etebaai I, Benjilani H, El Khoudri K, Reddad H, Taieb M (2016) Sedimentology and geochemistry of lacustrine terraces of three Middle Atlas lakes: paleohydrological changes for the last $2300 \mathrm{cal}$ BP in Morocco (western Mediterranean region). Quat Int 404:163-173. https://doi.org/10. 1016/j.quaint.2015.10.038 (ISSN 10406182)

Della Bella V (2019) Caratterizzazione e Di!Usione Delle Specie Aliene Acquatiche e Di Ambienti Umidi in Umbria. Arpa Umbria, Perugia

Dittrich M, Koschel R (2002) Interactions between calcite precipitation (natural and artificial) and phosphorus cycle in the hardwater lake. Hydrobiologia 469(1/3):49-57. https://doi.org/10.1023/A: 1015571410442 (ISSN 00188158)

Dragoni W (1982) Idrogeologia del Lago Trasimeno: Sintesi, problemi, aggiornamenti. Geogr Fis Dinam Quat 5:192-206

Dubois N, Saulnier-Talbot É, Mills K, Gell P, Battarbee R, Bennion H, Chawchai S, Dong X, Francus P, Flower R, Gomes DF, Gregory-Eaves I, Humane S, Kattel G, Jenny JP, Langdon P, Massaferro J, McGowan S, Mikomägi A, Ngoc NTM, Ratnayake AS, Reid M, Rose N, Saros J, Schillereff D, Tolotti M, Valero-Garcés B (2018) First human impacts and responses of aquatic systems: a review of palaeolimnological records from around the world. Anthr Rev 5(1):28-68. https://doi.org/10. $1177 / 2053019617740365$ (ISSN 2053-0196, 2053-020X)

Francke A, Lacey Jack H, Marchegiano M, Wagner B, Ariztegui D, Zanchetta G, Kusch S, Ufer K, Baneschi I, Knödgen K (2021) Last Glacial central Mediterranean hydrology inferred from Lake Trasimeno's (Italy) calcium carbonate geochemistry. Boreas, page bor.12552. ISSN 0300-9483, pp. 1502-3885. https://doi.org/10.1111/bor.12552

Frondini F, Dragoni W, Morgantini N, Donnini M, Cardellini C, Caliro S, Melillo M, Chiodini G (2019) An Endorheic Lake in a changing climate: geochemical investigations at Lake Trasimeno (Italy). Water 11(7):1319. https://doi.org/10.3390/w11071319 (ISSN 2073-4441)

Gaino E, Scoccia F, Piersanti S, Rebora M, Bellucci LG, Ludovisi A (2012) Spicule records of Ephydatia fluviatilis as a proxy for hydrological and environmental changes in the shallow Lake Trasimeno (Umbria, Italy). Hydrobiologia 679(1):139-153. https://doi.org/10.1007/s10750-011-0861-7 (ISSN 0018-8158, 1573-5117)

Gierlowski-Kordesch Elizabeth H (2010) Chapter 1 lacustrine carbonates. Dev Sedimentol 61:1-101. https://doi.org/10.1016/S0070-4571(09)06101-9

Giovanardi F, Poletti A, Micheli A (1995) Indagine sulla qualità delle acque del lago Trasimeno. Definizione dei livelli trofici. Acqua Aria, pp 627 
Goldsmith JR, Graf DL (1958) Structural and compositional variations in some natural dolomites. J Geol 66(6):678-693. https://doi.org/10.1086/626547 (ISSN 0022-1376, 1537-5269)

Gražulis S, Chateigner D, Downs RT, Yokochi AFT, Quirós M, Lutterotti L, Manakova E, Butkus J, Moeck P, Le Bail A (2009) Crystallography open database - an open-access collection of crystal structures. J Appl Crystallogr 42(4):726-729. https://doi.org/10.1107/S0021889809016690 (ISSN 0021-8898)

Guerra L, Piovano EL, Córdoba FE, Sylvestre F, Damatto S (2015) The hydrological and environmental evolution of shallow Lake Melincué, central Argentinean Pampas, during the last millennium. J Hydrol 529:570-583. https://doi.org/10.1016/j.jhydrol.2015.01.002 (ISSN 00221694)

Hartley AM, House WA, Callow ME, Leadbeater BSC (1997) Coprecipitation of phosphate with calcite in the presence of photosynthesizing green algae. Water Res 31(9):2261-2268. https://doi.org/10. 1016/S0043-1354(97)00103-6 (ISSN 00431354)

Holland HD, Zimmermann H (2000) The dolomite problem revisited ${ }^{1}$. Int Geol Rev 42(6):481-490. https:// doi.org/10.1080/00206810009465093 (ISSN 0020-6814, 1938-2839)

Koschel R, Giering B, Kasprzak P, Proft G, Raidt H (1990) Changes of calcite precipitation and trophic conditions in two stratified hardwater lakes of the Baltic Lake district of the GDR. SIL Proceed 19222010 24(1):140-145. https://doi.org/10.1080/03680770.1989.11898706 (ISSN 0368-0770)

Larson AC, Von Dreele RB (2001) Generalized crystal structure analysis system (GSAS) Los Alamos National Laboratory Report LAUR 86-748 (2004)

Last WM (1982) Holocene carbonate sedimentation in Lake Manitoba, Canada. Sedimentology 29(5):691704. https://doi.org/10.1111/j.1365-3091.1982.tb00074.x (ISSN 0037-0746, 1365-3091)

Liu D, Yangyang X, Qianqian Y, Na Y, Qiu X, Wang H, Papineau D (2020) Catalytic effect of microbiallyderived carboxylic acids on the precipitation of $\mathrm{Mg}$-calcite and disordered dolomite: implications for sedimentary dolomite formation. J Asian Earth Sci 193:104301. https://doi.org/10.1016/j.jseaes.2020. 104301 (ISSN 13679120)

Ludovisi A, Gaino E (2010) Meteorological and water quality changes in Lake Trasimeno (Umbria, Italy) during the last fifty years. J Limnol 69(1):174-188. https://doi.org/10.3274/j110-69-1-16 (ISSN 11295767)

Marchegiano M, Francke A, Gliozzi E, Ariztegui D (2018) Arid and humid phases in central Italy during the Late Pleistocene revealed by the Lake Trasimeno ostracod record. Palaeogeogr Palaeoclimatol Palaeoecol 490:55-69. https://doi.org/10.1016/j.palaeo.2017.09.033 (ISSN 00310182)

Marchegiano M, Francke A, Gliozzi E, Wagner B, Ariztegui D (2019) High-resolution palaeohydrological reconstruction of central Italy during the Holocene. Holocene 29(3):481-492. https://doi.org/10.1177/ 0959683618816465 (ISSN 0959-6836, 1477-0911)

Martín-Puertas C, Valero-Garcés BL, Pilar Mata M, Moreno A, Giralt S, Martínez-Ruiz F, Jiménez-Espejo F (2011) Geochemical processes in a Mediterranean Lake: a high-resolution study of the last 4,000 years in Zoñar Lake, southern Spain. J Paleolimnol 46(3):405-421. https://doi.org/10.1007/s10933009-9373-0 (ISSN 0921-2728, 1573-0417)

Martinelli A (2012) Tutela Ambientale Del Lago Trasimeno. Arpa Umbia, Perugia. ISBN 978-88-905920-0-3

Morellón M, Valero-Garcés B, González-Sampériz P, Vegas-Vilarrúbia T, Rubio E, Rieradevall M, Delgado-Huertas A, Mata P, Romero Ó, Engstrom DR, López-Vicente M, Navas A, Soto J (2011) Climate changes and human activities recorded in the sediments of Lake Estanya (NE Spain) during the medieval warm period and little ice age. J Paleolimnol 46(3):423-452. https://doi.org/10.1007/s10933-0099346-3 (ISSN 0921-2728, 1573-0417)

Morozzi G (1996) Relazione semestrale relativa allo studio dei sedimenti del Lago Trasimeno. Technical report, Provincia di Perugia

Müller German (1970) High-magnesian calcite and protodolomite in Lake Balaton (Hungary) sediments. Nature 226(5247):749-750. https://doi.org/10.1038/226749a0 (ISSN 0028-0836, 1476-4687)

Murphy TP, Hall KJ, Yesaki I (1983) Coprecipitation of phosphate with calcite in a naturally eutrophic lake: calcite-phosphate coprecipitation. Limnol Oceanogr 28(1):58-69. https://doi.org/10.4319/lo.1983. 28.1.0058 (ISSN 00243590)

Naeher S, Gilli A, North RP, Hamann Y, Schubert CJ (2013) Tracing bottom water oxygenation with sedimentary Mn/Fe ratios in Lake Zurich, Switzerland. Chem Geol 352:125-133. https://doi.org/10.1016/j. chemgeo.2013.06.006 (ISSN 00092541)

Otsuki A, Wetzel RG (1972) Coprecipitation of phosphate with carbonates in a Marl Lake. Limnol Oceanogr 17(5):763-767. https://doi.org/10.4319/lo.1972.17.5.0763 (ISSN 00243590)

Ribeiro DC, Martins G, Nogueira R, Cruz JV, Brito AG (2008) Phosphorus fractionation in volcanic lake sediments (Azores - Portugal). Chemosphere 70(7):1256-1263. https://doi.org/10.1016/j.chemosphere. 2007.07.064 (ISSN 00456535) 
Robert Folk L, Land Lynton S (1975) Mg/Ca ratio and salinity: two controls over crystallization of dolomite. AAPG Bull. https://doi.org/10.1306/83D91C0E-16C7-11D7-8645000102C1865D

Rodriguez-Blanco JD, Shaw S, Bots P, Roncal-Herrero T, Benning LG (2014) The role of Mg in the crystallization of monohydrocalcite. Geochim et Cosmochim Acta 127:204-220. https://doi.org/10.1016/j. gca.2013.11.034 (ISSN 00167037)

Sánchez-Román M, Romanek CS, Fernández-Remolar DC, Sánchez-Navas A, McKenzie JA, Pibernat RA, Vasconcelos C (2011) Aerobic biomineralization of Mg-rich carbonates: implications for natural environments. Chem Geol 281(3-4):143-150. https://doi.org/10.1016/j.chemgeo.2010.11.020 (ISSN $00092541)$

Smol JP, John H, Birks B, Last WM, Bradley RS, Alverson K (eds) (2001) Tracking environmental change using Lake Sediments: terrestrial, algal, and siliceous indicators, volume 3 of developments in paleoenvironmental research. Springer Netherlands, Dordrecht. https://doi.org/10.1007/0-306-47668-1 (ISBN 978-1-4020-0681-4 978-0-306-47668-6)

Solotchina ÈP, Solotchin PA (2014) Composition and structure of low-temperature natural carbonates of the calcite-dolomite series. J Struct Chem 55(4):779-785. https://doi.org/10.1134/S00224766140402 95 (ISSN 0022-4766, 1573-8779)

Stabel H-H (1986) Calcite precipitation in Lake constance: chemical equilibrium, sedimentation, and nucleation by algae1: calcite sedimentation. Limnol Oceanogr 31(5):1081-1094. https://doi.org/10.4319/lo. 1986.31.5.1081 (ISSN 00243590)

Stumm W, Leckie J (1971) Phosphate exchange with sediments: its role in the productivity of surface waters. In: Proceeding 5th Int Conf on Adv in Water Pollution Res, 2

Tompa É, Nyirô-Kósa I, Rostási Á, Cserny T, Pósfai M (2014) Distribution and composition of Mg-calcite and dolomite in the water and sediments of Lake Balaton. Cent Eur Geol 57(2):113-136. https://doi. org/10.1556/CEuGeol.57.2014.2.1 (ISSN 1788-2281, 1789-3348)

U.S. EPA (1996) Method 3050B: acid digestion of sediments, sludges, and soils, Revision 2, Washington, DC

Valero-Garcés BL, González-Sampériz P, Navas A, Machín J, Mata P, Delgado-Huertas A, Bao R, Moreno A, Carrión JS, Schwalb A, González-Barrios A (2006) Human impact since medieval times and recent ecological restorationin a Mediterranean lake: the laguna Zoñar, southern Spain. J Paleolimnol 35(3):441-465. https://doi.org/10.1007/s10933-005-1995-2 (ISSN 0921-2728, 1573-0417)

Viotti P (2014) A study on phosphorus flux from sediment in a shallow Homogeneous lake. Ann Acad Rom Sci Vol 1(Series on Chemistry Sciences). ISSN 2393 - 2902

Yamamuro M, Kanai Y (2005) A 200-year record of natural and anthropogenic changes in water quality from coastal lagoon sediments of Lake Shinji, Japan. Chem Geol 218(1-2):51-61. https://doi.org/10. 1016/j.chemgeo.2005.01.021 (ISSN 00092541)

Zan F, Huo S, Xi B, Jing S, Li X, Zhang J, Yeager KM (2011) A 100 year sedimentary record of heavy metal pollution in a shallow eutrophic lake, Lake Chaohu, China. J Environ Monit 13(10):2788. https:// doi.org/10.1039/c1em10385g (ISSN 1464-0325, 1464-0333)

Zhang F, Xu H, Konishi H, Roden EE (2010) A relationship between d104 value and composition in the calcite-disordered dolomite solid-solution series. Am Mineral 95(11-12):1650-1656. https://doi.org/ 10.2138/am.2010.3414 (ISSN 0003-004X)

Zhang Z, Xie Y, Xurong X, Pan H, Tang R (2012) Transformation of amorphous calcium carbonate into aragonite. J Cryst Growth 343(1):62-67. https://doi.org/10.1016/j.jcrysgro.2012.01.025 (ISSN 00220248)

Zohary T, Ostrovsky I (2011) Ecological impacts of excessive water level fluctuations in stratified freshwater lakes. Inland Waters 1(1):47-59. https://doi.org/10.5268/IW-1.1.406 (ISSN 20442041, 2044205X)

Zolitschka B, Francus P, Ojala AEK, Schimmelmann A (2015) Varves in lake sediments - a review. Quat Sci Rev 117:1-41. https://doi.org/10.1016/j.quascirev.2015.03.019 (ISSN 02773791)

Publisher's Note Springer Nature remains neutral with regard to jurisdictional claims in published maps and institutional affiliations. 